
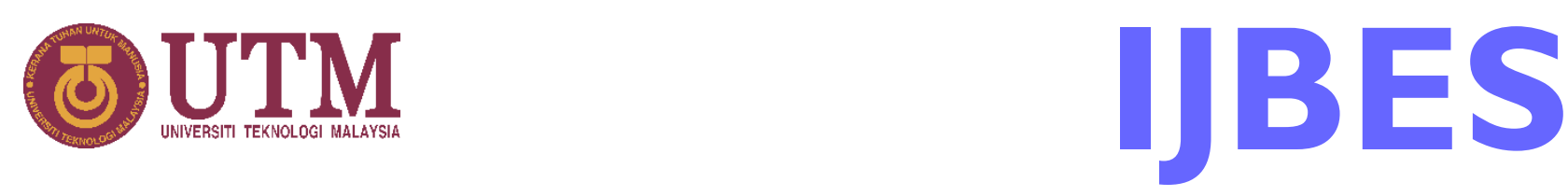

International Journal of Built Environment and Sustainability Published by Penerbit UTM Press, Universiti Teknologi Malaysia

IJBES 8(2)/202I, 89-I02

\title{
Suitable Locations for Industrial Setup in Urban Context: Way Forward To Meet the SDGs for Khulna City, Bangladesh
}

\author{
Md. Nazmul Haque \\ Department of Urban and Regional Planning, Khulna University of Engineering \& Technology (KUET), Bangladesh \\ Mizbah Ahmed Sresto and Sharmin Siddika \\ Department of Urban and Regional Planning, Khulna University of Engineering \& Technology (KUET), Bangladesh
}

\begin{abstract}
Industrial Site selection is one of the rudimentary decisions to expand or relocate any business start-up process. This paper aimed at finding suitable location for possible industrial site as per reaching the SDGs taking Khulna City as a case. For instance, the targeted SDGs Goal 9: Resilient Infrastructure, Sustainable Industrialization and Innovation. The research also focused on the existing locations of the industries in the Khulna city and filled the gap to propose the new locations. To achieve this, a threestage method have been adopted. At first, the existing industries were categorized on the basis of basic/non-basic, small/large scale, input/output characteristics in geospatial environment. Location Quotient (LQ) technique was applied to detect basic, non-basic industries and industrial zone. Then, Analytic Hierarchy Process (AHP) was conducted to define weights of important criterion such as temperature, slope, water body, land use, city center, connectivity and structures. The calculation of Consistency Ratio $(\mathrm{CR}<0.1)$ showed rational consistency of the factors. Finally, Multi Criteria Decision Analysis (MCDA) was adopted in GIS platform to address the suitable locations. The analysis shows $10 \%$ of the total KCC area is suitable for constructing industrial zones. According to the results most of the suitable land was found in the eastern side and a few suitable lands was found in the upper western part of the map. Another findings state that, $5 \%$ change in vacant land can increase this percentage to $17 \%$ which eventually escalates sustainability, resilience and locational advantages. In addition, the study assesses the land use change in Khulna City Corporation for recent years which have potential for industrial establishment through land suitability analysis (LSA) to emphasize both land use and industries with sustainable development.
\end{abstract}

(C) 2021 Penerbit UTM Press. All rights reserved

\section{Article History}

Received : 10 August 2020

Received in revised form: 03 January 2021

Accepted: 18 February 2021

Published Online: 30 April 2021

Keywords:

Analytic Hierarchy Process (AHP), Industrial zone, Multi Criteria Decision Analysis (MCDA), Site Suitability, Sustainable development.

\section{Corresponding Author Contact:}

nhaque13@urp.kuet.ac.bd

DOI: $10.11113 /$ ijbes.v8.n2.679

\section{Introduction}

Bangladesh is a country of rivers located in South Asia with a coastline of $580 \mathrm{~km}$ in the north coast of the Bay of Bengal ( Islam, Hossain, Abbas, Silvy, \& Hasan, 2020). Over the past four decades, Bangladesh has undergone significant structural changes in the economy. The contributions of industrial and service sectors have expanded ( Salam, 2016). In developing countries like Bangladesh main focus is given on greater production ( Islam, Banik, Sakib, \& Begum, 2018). Bangladesh is one of the fastest growing economies of Asia with an amazing growth in the last 10 years (Islam, Bhattacherjaa, \& Fatema, 2019). Industrialization 
across major economies of the world has led to various economic, social, and environmental opportunities as well as challenges ( Gupta \& Racherla, 2016). Economic development is the process of structural transformation from traditional agriculture to modern agriculture, industries and services (Fernando, Pinnawala , \& Edussuriya, November-2015). The greater the level of urbanization, the greater the contribution of cities are observed to the GDP and thus in economic growth ( Rahman \& Kabir, 2019). For achieving economic growth and better GDP sustainable development is important. The Sustainable Development Goals (SDGs) were adopted by the United Nations (UN) at the end of 2015 immediately after achievement of the MDGs. SDGs agenda was adopted after wide consultation with governments, civil society and development partners to agree on a new agenda which would be inspirational for global development. The SDGs connect people, planet, and prosperity, and provide a framework for all countries, developed and developing alike, to pursue a better way for development (Paul, 2019). The SDGs seek to achieve what MDGs were unable to achieve. On September 25, 2015, the UN General Assembly adopted the Agenda of 2030 for Sustainable Development to push humanity towards a sustainable path. UN is committed to achieve sustainable development in its three dimensions economic, social and environmental in a more balanced and integrated manner. Sustainable development envisage a world in which every country enjoys sustained, inclusive economic growth and decent work for all. A world in which consumption and production patterns and use of all natural resources from air to land, from rivers, lakes and aquifers to oceans and seas are sustainable (NATIONS, 2018). SDG's $9^{\text {th }}$ goal states "Build resilient infrastructure, promote inclusive and sustainable industrialization and foster innovation." (Paul, 2019). In a developing country like Bangladesh it is important to develop inclusive and sustainable industrialization. Finding a suitable geographic focus for the industry is very important for the administrator of the company, investors and government ( Moses, Iwara, Gbadebo, Olubukola, \& Omin, 2018). Suitable site selection of industrial zone is critical point in the process of starting, expanding or changing the location of industrial system (Hadipour \& Kishani, 2014). Several reports indicate industrial areas are the second most important factor which increased the problems of toxic pollution worldwide (Fernando, Pinnawala , \& Edussuriya, November-2015). Most high-income countries have strict rules and codes for their industrial areas, but in some low and middle-income countries, little is done to protect the surrounding communities waste and by-products of these concentrated industries (Fernando, Pinnawala , \& Edussuriya, November-2015). The choice of the industrial site is a strategic decision that involves several criteria for review of technical, economic, social, environmental and political issues (Rikalovic, Cosic, Labati, \& Piuri, 2017). In a selection process of industrial site, analysts strives to determine the optimal location that meets the selection criteria (Hadipour \& Kishani, 2014). Historically raw materials, transportation, and industrial energy are considered as important factors for industries ( Rahman \& Kabir, 2019).

A number of tools can be used to determine the appropriate site for industrial location. Mapping tools include Geographic
Information System (GIS), the image processing system and remote sensing techniques. GIS and remote sensing provide a wide range of capabilities for the industrial zone mapping, monitoring and facilitating decision making process and GIS techniques for industrial site selection. (Fernando, Pinnawala, \& Edussuriya, November-2015) addressed a GIS based model for site selection process. (Boutkhoum, Hanine, Agouti, \& Tikniouine, 2014) developed Fuzzy AHP and OLAP based model for strategic industrial location selection.

The main motive of the research is to identify the existing condition of industries in KCC area and to find out suitable locations for developing new industries in future to attain SDGs goal 9. Suitable site selection for industries is one of the fundamental steps of sustainable industrialization (Nations, 2015). This research will push one step forward to achieve sustainable industrialization in context of Khulna city. In this research AHP (Areal Hierarchy Process) and GIS based weighted overlay analysis was done to fulfill the objective. Khulna is a city with numerous industries of various categories ( Partha, Mohaimin, \& Islam, 2018). Present conditions of the industries in Khulna city indicates that there is somewhat less management to achieve optimization of utilization and conservation ( Johar, Jain , \& Garg , 2013). Moreover, they are not resilient as stated in SDGs goal. Choosing the correct location can help an industry to bring out more profit. Even it can reduce the cost of transportation, cost of labor and cost of raw materials and create more employment opportunities. It is quite necessary for construction industries because it generates jobs which in turn increases the people's source of income that makes not only economically stable people, but also the economy of the state in general (M , Saran , \& Ramana , 2018).

Researchers have developed different methodologies for identifying suitable locations for industries. For example ( Fataei, erdi , Farhadi, \& Mohammadian, 2015) established integrated index overlay and weighting method of AHP for environmental planning and location choice. Khulna is a port city on the banks of Rupsha and Bhairab River. As a result the southern region has become a hub of the Bangladeshi industry. It hosts many national companies. After the construction of Padma Multipurpose Bridge it will link south-west region of the country to the north-east region and industrial growth will be faster ( Islam, Hossain, Abbas, Silvy, \& Hasan, 2020). It is high time to take initiative for identifying the suitable locations for developing new industries in Khulna city.

\section{Methodology}

In this section various steps and tools assembling considering proposed methodology, starting from evaluation of the selected criteria, assessment of potential alternatives and finally, presentation of the final results were discussed. 


\subsection{Area of Study}

Khulna is the third largest city of Bangladesh located within 22 51 ' 8 " north latitude and $89 \square 32$ '35" east longitude. It has an area of 4389 square kilometers with a population of 2,318,527. The district is bounded by Joshore and Narail on the north, Bagerhat on the east, Satkhira on the west and Bay of Bengal on the south. It has an elevation of $9 \mathrm{~m}$ from mean sea level and is considered to be a low lying city. The soil condition here is mostly black peat, dark grey clay and sulphate grey silty clay (Ahmmed, et al., 2013). Khulna City Corporation consists 64.76 square kilometer of land area with 31 wards (Figure 1). The total population of $\mathrm{KCC}$ is 0.7 million and approximately 16,268 people live in per square kilometer here. There are about 320 small and large water bodies located in the city. Different industries are playing an important role in the socio-economic structure of Khulna city (Haque, Mamun, Saroar , \& Roy, 2019). The industries could be classified into diverse sector such as, timber and furniture, bakery and food processing, leather industries machineries, fisheries, manufacturing and Agro-processing. These industries are often found to be clustered along the major road of the city and on the open space along the river Bhoirab (Ahmmed, et al., 2013)

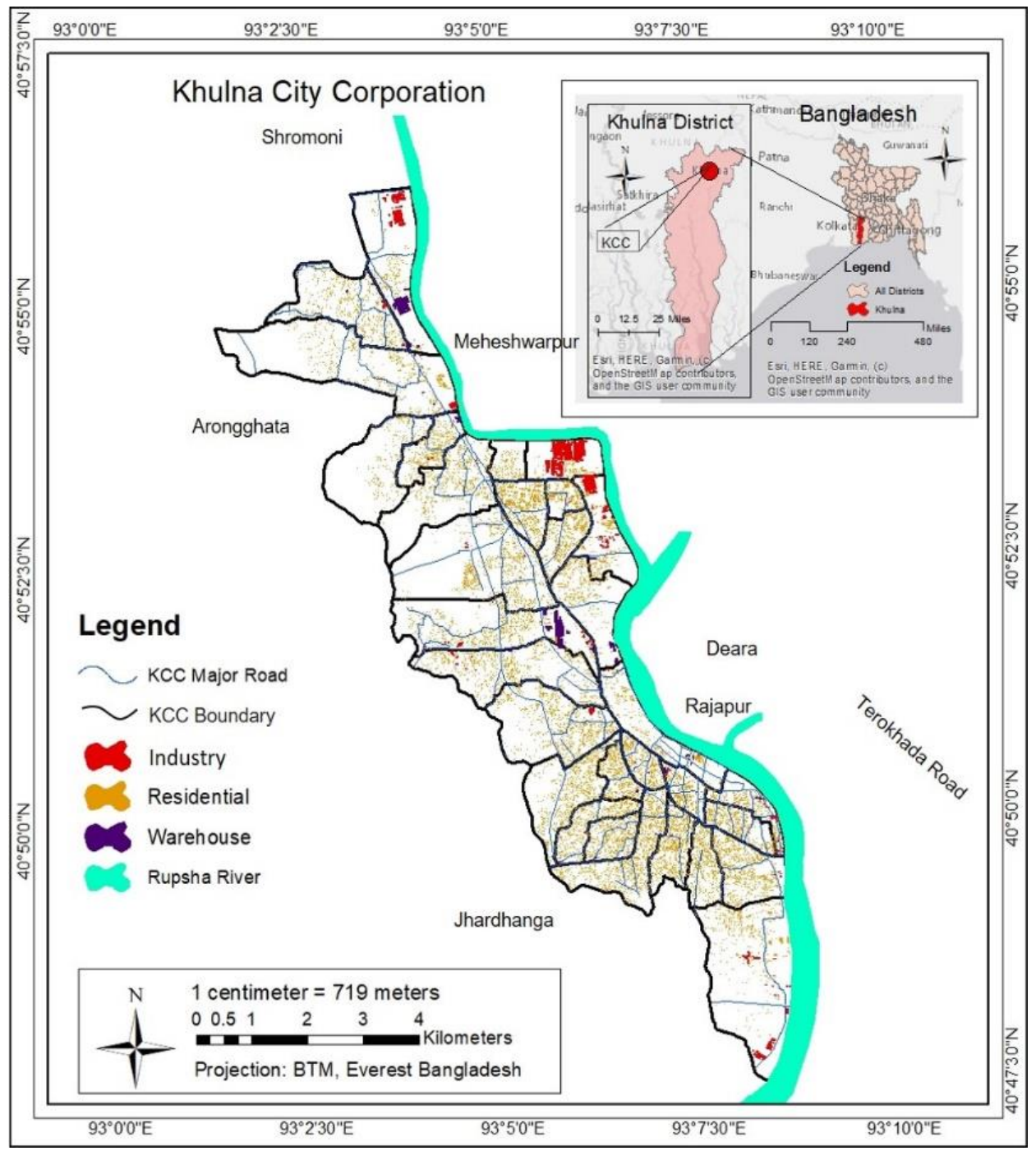

Figure 1 Study Area Map (Author, 2020) 


\section{$2.2 \quad$ Methods}

A conceptual illustration that reflects the methodological approach for this research is given below in figure 2. Here the breakdown of each stages is shown so that, the whole process can easily be summarized.

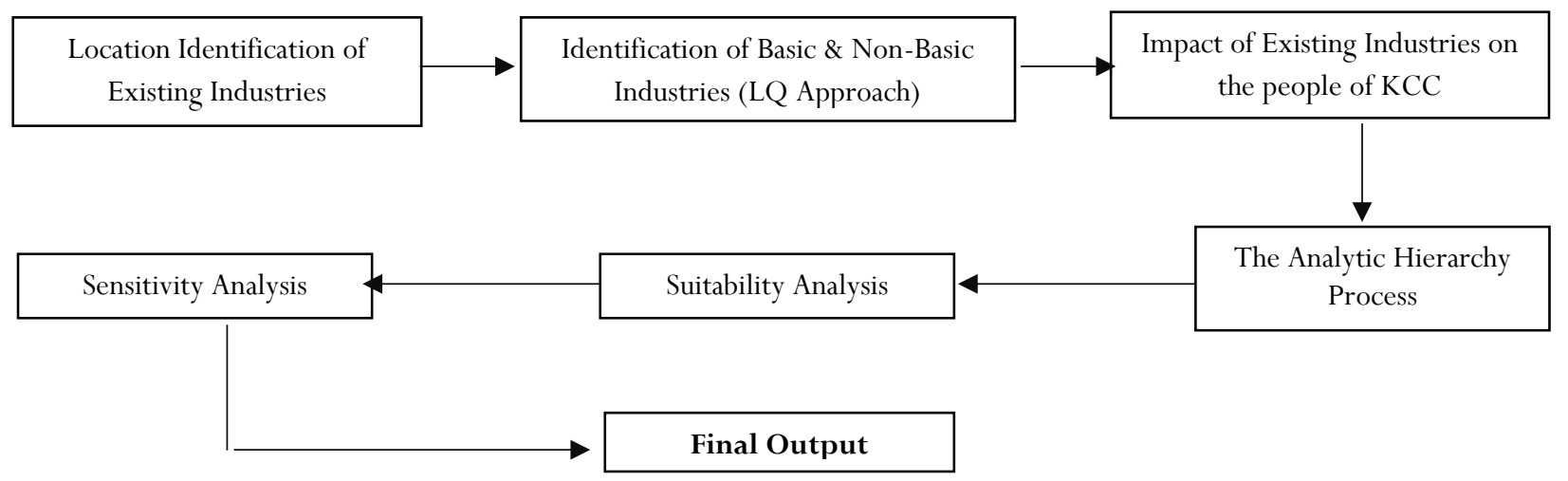

Figure 2 Methodological Framework (Author, 2020)

\subsubsection{Identifying Basic and Non-Basic Industries -}

Location Quotients Approach

According to Florence, (S., 1937) location quotient is the number of the concentration of any certain industry in an area and comparing it will all the persons involved in that particular industry of the given area with consisting proportion for the country. It is an important tool that helps to determine and evaluate the size and strength of a particular industry in a region. (Goodwin, 2018). Location quotient is a technique to study economic condition of a region, to identify economic sectors of a region, to assess condition of each economic sector and to evaluate the impact of different development or investment (Wang \& Hofe, 2007).

The Location Quotient equation can be represented by-

Where,

$$
L Q_{i}=\frac{e_{i} E}{e E i}
$$

$\mathrm{e}_{\mathrm{i}}=$ Local employment in industry $\mathrm{i}$

$\mathrm{e}=$ Total local employment

$E_{i}=$ National employment in industry $i$

$\mathrm{E}=$ Total national employment

If, $\mathrm{LQ}=1$ it indicates local industries are producing just enough output to satisfy local needs.

LQ>1 indicates local industries are producing an excess for export. (Basic industry).

$\mathrm{LQ}<1$ indicates local industries are not producing enough to export and products need to be imported (Non-Basic).

\subsubsection{Data Collection}

Secondary data on suitable site selection for industrial location has been collected from online questionnaire survey. A total of 215 people participated in this survey. Other important sources comprises of Khulna Civil Surgeon Office, KCC Ward Office, $\mathrm{KCC}$ and $\mathrm{KDA}$. Industrial zones were created in a clustered way following current agglomeration of various industries.

\subsubsection{Multi-Criteria Decision Analysis (MCDA)}

Multi-criteria decision analysis can classify multi-criteria decision-making problems based on major components of it such as multi-objective decision analysis (MODA) and multi-attribute decision making (MADA), group decision making problems to individual decision-making problems and decision under certainty and uncertainty (Rikalovic, Cosic and Lazarevic 2014). There are three phases a multi-criteria decision analysis can be performed (Rikalovic, Cosic, Labati, \& Piuri, 2017). Firstly, definition of the criteria weights. Then estimation of the consistency ratio and finally evaluation and ranking of the location alternatives.

To determine the first phase Analytic Hierarchy Process is applied.

The Analytic Hierarchy Process (AHP)

The Analytic Hierarchy Process (AHP) is introduced initially by Saaty (1980), is a powerful and flexible methodology in the solution of complex decision-making problems (Boutkhoum, et al. 2014). It is a pairwise comparison technique to identify the relative relevance of criteria (Rikalovic, Cosic, Labati, \& Piuri, 2017). Analytic Hierarchy Process (AHP) has been used in multicriteria decision making to release the restriction of hierarchical structure. It has been applied to environmental studies, project selection, product planning, strategic decision, supply chain management system analysis and other fields (Hadipour \& Kishani, 2014). In this paper Spatial AHP is used to spot suitable sites for industries and to quantify the levels through categorization and usage of knowledge, facts based user preference and data contained in GIS map (M, Saran, \& Ramana, 2018). The most difficult task in carrying out land suitability analysis approach for an exacting land use type is to assign the relative weights of the entity criteria that are to be considered. Thus, the study limited the criteria to the nine most important aspects. 
Table 1 Saaty's Scale

\begin{tabular}{|c|c|}
\hline Intensity of Importance on an Absolute Scale & Numeric Rating \\
\hline - $\quad$ Equal importance & 1 \\
\hline - Moderate importance of one over the other & 3 \\
\hline - Essential or strong importance & 5 \\
\hline - Very strong importance & 7 \\
\hline - Extreme importance & 9 \\
\hline - Intermediate values between two adjacent judgments & $2,4,6,8$ \\
\hline
\end{tabular}

Source: (M, Saran, \& Ramana, 2018)

AHP is divided into 4 step- (Zahedi, 1986)

Step 1 - The creation of the hierarchy decision to break the decision problem into a hierarchy of decision elements which are related.

Step 2- Collecting input data by pairwise comparison of decision elements.

Step 3- Using the method of eigenvalues to estimate the relative weights of the decision elements.

Step 4- Aggregating the relative weights of decision elements to arrive a set of ratings for the decision alternatives.

In the second phase the steadiness of the obtained criteria weights should be considered. Decision makers are rarely stable in estimating these weights in pairwise comparisons. Firstly evaluate the Consistency Vector, $\lambda$ was done by multiplying the pairwise comparison matrix with the vector of the criteria weights (Rikalovic, Cosic, Labati, \& Piuri, 2017). The Consistency Index $\mathrm{CI}$, of the envisioned pairwise comparison matrix is defined as-

$$
C I=\frac{\lambda \max -n}{n-1}
$$

Where, $\lambda_{\max }=$ Average value of the consistency vector, $\mathrm{n}=$ Number of criteria

The Random Index, RI, provides a reference for consistency when the comparison matrix is created without any agreement between decision makers on criteria weights. The Consistency Ratio, CR, measures the agreement among the decision makers, such as how much the pairwise comparison matrix ratings were randomly generated instead of being based on an objective, shared view of criteria among decision makers. The consistency ratio is defined as-

$$
C R=\frac{C I}{R I}
$$

A value of $\mathrm{CR}<0.1$ gives reasonable consistency. If there is any inconsistency considering the criteria weight the pair-wise comparison should be stimulated again.

The last phase of AHP is to aggregate the following equation of suitability index, S

$$
S=\sum w_{i^{*}} x_{i}
$$

Where, $\mathrm{w}_{\mathrm{i}}=$ Criteria weight, $\mathrm{x}_{\mathrm{i}}=$ Criteria value

\subsubsection{Sensitivity Analysis}

Sensitivity analysis is a method used for evaluating how sensitive the spatial multi-criteria model output is to small changes in the input values. This approach aims at analyzing the effects of introduced perturbations in the input values on the output.

The two most important essentials to consider in sensitivity analysis are criterion weights and attribute values. Out of these, sensitivity to attribute weights is perhaps more important. If the ranking of alternatives proves to be sensitive to one or more weights, the accuracy in estimating weights should be inspected carefully (M, Saran, \& Ramana, 2018).

\section{Analysis \& Findings}

\subsection{Land Use of Khulna City Corporation}

From Figure 3 it is clear that almost $49.45 \%$ area of Khulna City Corporation is build up. The amount of vacant land is relatively less with respect to the amount of water bodies, vegetation and build up area. $25.25 \%$ land is covered with vegetation and only $16.65 \%$ area is covered with water bodies. Industrial zones have additional advantage if they are located near riverside or major road or railway. This is crucial for transporting goods and products easily and efficiently. River has been performing as a primary medium to carry heavy loads, manufacturing goods and materials for a very long time. Within $\mathrm{KCC}$ the area along Bhoirab River is already used for residential, commercial and small industrial purpose. As a result there are a few suitable places for establishing new industries. If the industries grow haphazardly then it might impact badly on people living in urban areas and industries might not gain profit. So the less amount of vacant land $(8.35 \%)$ should be used wisely and the industries should be relocated carefully. Relocating alone cannot solve problems if the vacant land is not suitable enough or does not fulfill all criteria of site suitability. It should be not be interspersed with residential zone and have minimum proximity to it. No vegetation land should be demolished in order to build industrial zone. Figure 3.1also illustrates that ward-01, 03, 04 and 05 has relatively dense vegetation compared to remaining wards. These lands should not be occupied to form industrial zone. SDGs goal 9 also promotes inclusive and sustainable industrialization and no sustainable industrialization is possible without proper utilization of land. Categorizing buildup areas according to proper planning is crucial for industrial development. 


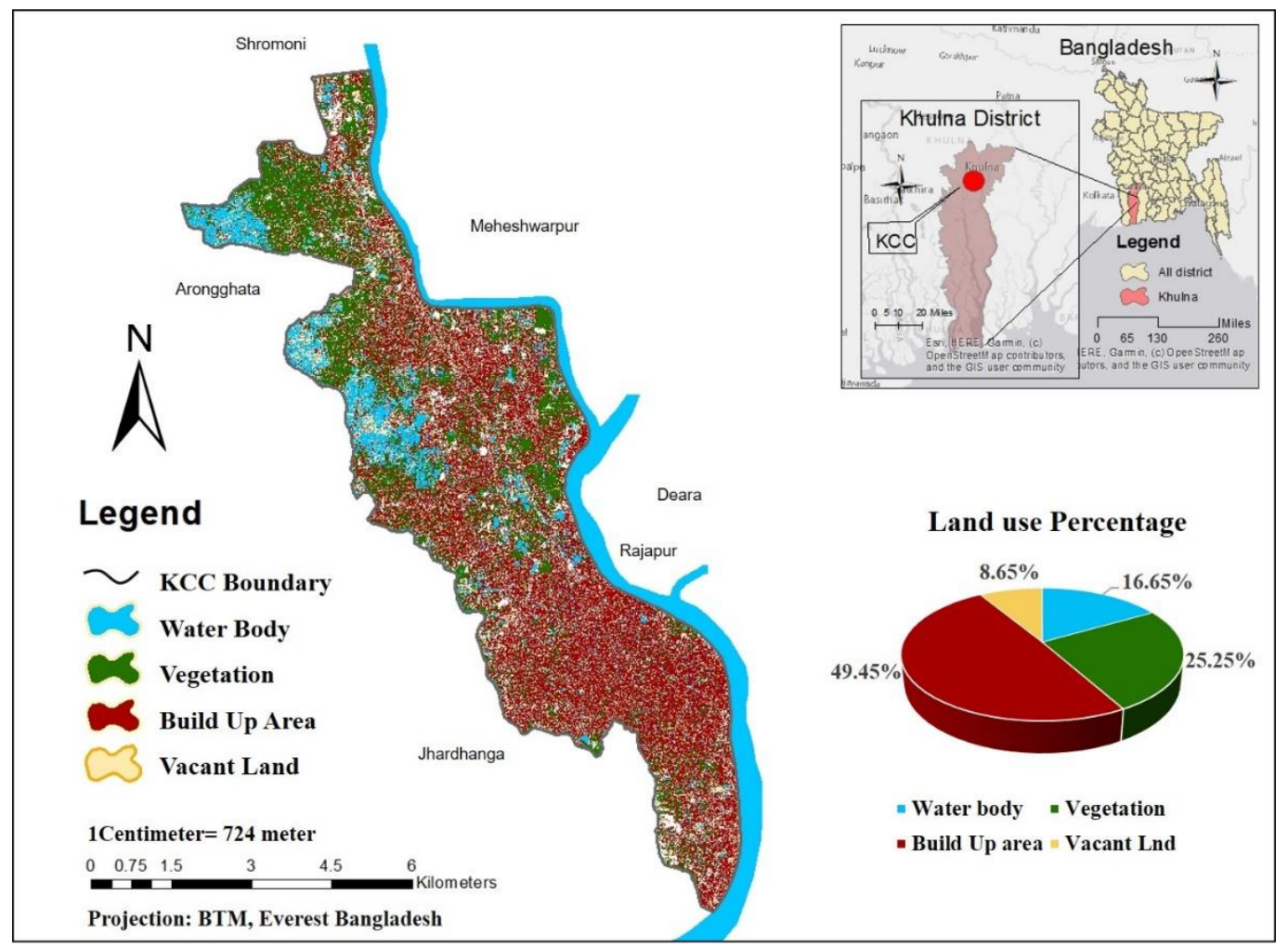

Figure 3 Land use map of KCC (Author, 2020)

\subsection{Condition of Existing Industries}

Figure 4 (a) shows not only the location of the current industries but also the variety of industries located in the study area. From suitability analysis for industrial location it is observed that most of the industrial location should follow a boundary line such as riverside area, alignment of the roads and railway. Khulna is an old, unplanned city. Most of the wards of $\mathrm{KCC}$ are not shaped in a planned way. As the population grew rapidly demand for goods and services increased. To fulfill the local demand several industries began to burgeon everywhere in the city. There are approximately 374 small and large industries currently functioning in Khulna City Corporation. They not only causes environmental pollution but also damages the surroundings of the area. But in few cases some of the industries such as wire and cable manufacturing industries in ward-02, jute mills in ward-08, hardboard and paper factories in ward-13, rice mills in ward-16 and ward-31 are built along river shore and along the major road. They are clustered in manner and have an internal cycle for input and output product. On the contrary, some of the industries are scattered in manner. They are constructed haphazardly and without any planning. Because of this, the overall production of industries are hampered. Products are not being transferred to the large industries from small industries. Most of the time these industries cause complications and spoils the balance of surrounding zones. These issues are causing hindrance in achieving SDGs goal 9. Garment factories, plastic recycling factories, agro based industry and machinery repair industry in ward-09, 14, 17, 25 are such industries. Wire and cable industry, wood and wood product factories, jute mills are industries that yields goods and products in a large scale. These are large scale industries and they transport goods in regional and national market. Whereas, rice mills, saw and hardboard industries, plastic and paper factories are small scale industries. They only occupies the local market. Indicator 9.a.1. In SDGs goal 9 emphasizes on governments effort in building wellstructured and well-planned industries to support its objective of achieving accelerated growth and poverty reduction and this objective is only achievable by creating sustainable industrial zones and quality infrastructures (Bangladesh Planning Commission, 2018). Over the last two decades manufacturing sector in industries has been expanding steadily in Bangladesh. Dominant segments of the sector such as textiles, furniture, jute goods, and leather are labor intensive. Therefore, the employment in these industries have also been increased. Advanced growth of industrial output has resulted in higher proportion of employment in the sector (Bangladesh Planning Commission, 2018). 
Table 2 Calculating Location Quotient for Basic, Non-Basic Industry

\begin{tabular}{|c|c|c|c|c|c|}
\hline $\begin{array}{c}\text { Types of Manufacturing } \\
\text { Industries }\end{array}$ & $\begin{array}{c}\text { National } \\
\text { Employment } \\
\left(\mathrm{E}_{\mathrm{i}}\right) \\
\end{array}$ & $\begin{array}{c}\text { Total National } \\
\text { Employment } \\
\text { (E) }\end{array}$ & $\begin{array}{c}\text { Local } \\
\text { Employment } \\
\text { (e) } \\
\end{array}$ & $\begin{array}{c}\text { Total Local } \\
\text { Employment } \\
\left(\mathrm{e}_{\mathrm{i}}\right) \\
\end{array}$ & $\begin{array}{l}L Q_{i}= \\
\left(\frac{e_{i} E}{e E i}\right)\end{array}$ \\
\hline 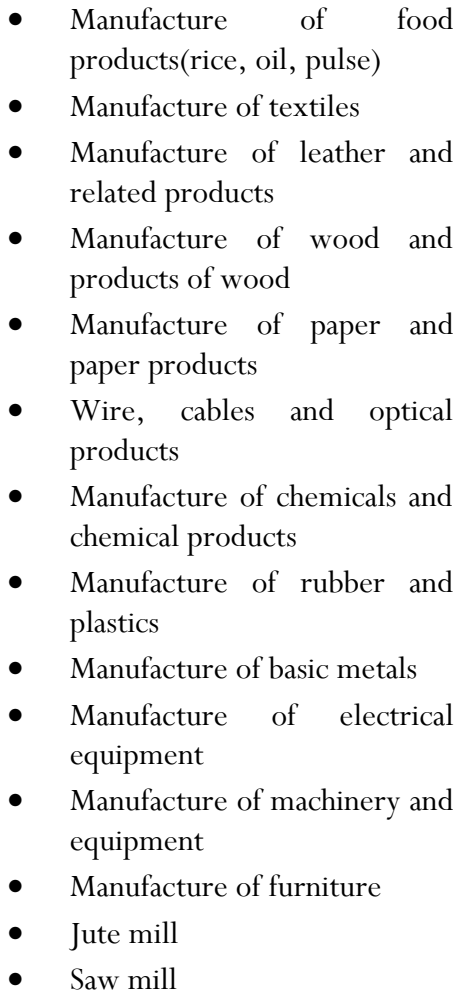 & $\begin{array}{l}280,257 \\
805,508 \\
75,524 \\
8528 \\
42,376 \\
16,390 \\
52594 \\
41,139 \\
120,965 \\
44,556 \\
10,001 \\
33,143 \\
187,000 \\
95,422\end{array}$ & $5,015,936$ & $\begin{array}{c}1032 \\
106 \\
888 \\
593 \\
694 \\
420 \\
\text { Null } \\
30 \\
356 \\
300 \\
120 \\
556 \\
19,253 \\
1154\end{array}$ & 121,421 & $\begin{array}{l}0.152 \\
0.005 \\
0.485 \\
2.872 \\
0.676 \\
1.058 \\
\text { Null } \\
0.030 \\
0.122 \\
0.278 \\
0.496 \\
0.693 \\
4.253 \\
0.499\end{array}$ \\
\hline
\end{tabular}

Source: (Statistics and Informatics Division (SID), 2013), (Economic Census 2013 District Report: Khulna, 2016), (Bangladesh Statistics , 2018), (Statistics and Informatics Division, 2013).

It is known that, when the location quotient value of an industry is less than 1, the industry is known to be non-basic which means the products that industry produces only able to fulfill the need of local demand. From table 1 it is observed that in Khulna City Corporation (KCC) most of the industries are non-basic type. Factories such as rice and pulse mills, oil mills produce goods in small scale. Similarly, the number of garment establishments are scarce in Khulna City Corporation, so it is considered as non-basic industry. Shoes, belts, bags and other leather products are produced in small quantity to meet the need of local market indicating a non-basic market in corresponding sector. Khalispur Newsprint Mill Ltd and Hardboard Mill Ltd. is the first newsprint mill in Bangladesh that once produced glut of pulp, mechanical pulp, board, paper and paper made products to hold both local and regional market. But its production capacity and quality reduced and in 2001 the authority was under the debt of almost 100 billion. As a result, once appraised industry unit of public sector is now on the brink of collapsing (Khulna newsprint mills (KNM), 2008). Thus, it is categorized as non- basic. Plastic and rubber products, basic metals, manufacture of electrical equipment, manufacture of furniture, saw mills are also nonbasic. They have a balanced market but only in local territory. Most of the times these products are required to be imported from outside. Plastic recycling and rubber production has little to no manufacturing progress in KCC. Whereas, manufacturing furniture have far many possibilities. On the contrary, from Table 2 in KCC there are a few industries that could be categorized as basic industries such as manufacturing wood and wood products, wire, cable and optical products and Jute factories. Wood, especially Gewa, Goran of Shundarbans, Mehgoni are the primary raw materials in these factories. Due to the abundance of wood in this region wood factories are burgeoning. From field survey it is observed that ward-02 of KCC has a flourishing wire, cable and optical industrial zone. It transports their products in national and international market thus considered as basic industry. Jute is another basic industrial sector that exports raw materials and jute made products in foreign countries. In $\mathrm{KCC}$ there are approximately 19,253 workers working in government and nongovernmental jute mills (Statisics and Information Division, 2013). It is a significant economic sector in the Khulna. If we focus on increasing efficiency of basic industries, create agglomerated industries so that one industries output can be other industries input it will help developing economy of KCC. One of the targets of SDGs goal 9 is to increase the access of small scale industries and other enterprises, in developing countries such as Bangladesh. For this, agglomeration of basic, non-basic 
industries, ensuring conducing policy environment and industrial diversification is necessary.

Figure 4 (b) Shows the industrial zone of basic and non-basic industries in Khulna City Corporation. It is perceived that Ward02, 08, 13, 16, 22, 31 has been developed as industrial zone. Industries are agglomerated in manner. Zone-01 comprises of jute mills that is basic in nature. Zone -02 has agglomeration of wire and cable industries that is basic in manner. Zone-03 consists of non-basic industries such as agro-based industry and paper mills. Zone-04 is considered as non-basic industry as it includes small scale mills such as rice mill, pulse mill, oil mill and food processing. Zone-05 and zone-07 also represents non-basic industries such as saw and hardboard industries, rice mills, agro based industry. Finally zone-06 has several wood and wood product manufacturing industries which are basic.

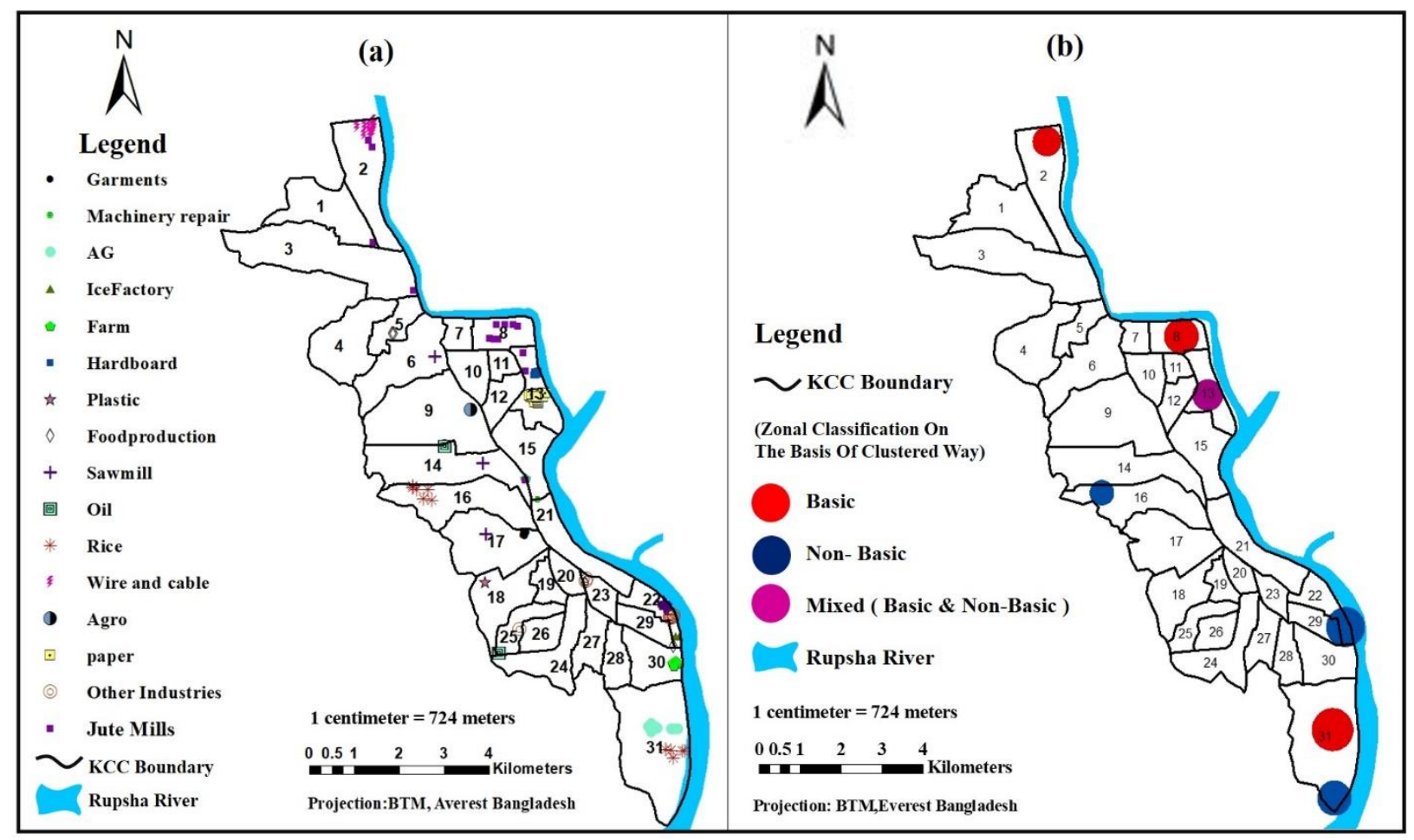

Figure 4 (a) Location of existing industries with the spatial extent; (b) Zonal Classification of the existing industries inside the KCC (Author, 2020)

\subsection{Impact of Industrial Zones inside KCC}

From questionnaire survey it is found that about $27 \%$ people prefer living nearby industrial zone and $73 \%$ people demurred living near industrial zone. Even $64.9 \%$ of the people think that they have safety issues living near industrial zones. According to their opinion $48.6 \%$ people are concerned about fire hazards, $35.1 \%$ people are concerned about chemical reaction and rest of them responded that they do not have any safety issues (Table 4).

Table 3 Service Facilities from Nearby Industry

\begin{tabular}{ll|c}
\hline Types of Facilities & Percentage \\
\hline - & Availability of Goods \& Services & $21.5 \%$ \\
- & Lower Cost of Products & $15 \%$ \\
- No Facility & $63.5 \%$ \\
\hline \multicolumn{2}{c}{ Source: Field Survey, 2020 }
\end{tabular}

Having industrial zone located near residential area or mixed areas such as residential-industrial zone has some advantages. It not only creates job opportunities for the residents but also aids economic growth of that particular area. It attracts other corresponding industries such a cable manufacturing factory would require factories that provides raw materials for example copper wire and plastic cover. A furniture making industry would require wood processing factories and raw woods for production. This will create an industrial agglomeration. The survey data shows almost $21.5 \%$ of the residents get easy accessibility to 
consumer goods and services due to residing near an industrial zone. $15 \%$ of the residents informed that cost of certain products are lower proximate to the area of production. Industries locating near residential area have some disadvantages too. Harmful gases from plastic manufacturing industries, cable factories, leather and shoe factories, jute mills has fatal effects on the health condition of residents. $17 \%$ of the residents complained about facing difficulties because of smoke and burning of coal and fossil fuel. Moreover, heavy machineries produce excessive noise pollution that detriments the condition of public health and environment. $48.6 \%$ of the inhabitants have acknowledged that they face noise pollution created from nearby industries. Industrial agglomeration can also cause heavy traffic congestion if traffic is not controlled systematically and if industries are sprouted abruptly without planning and provision. $10.5 \%$ of the residents have complained facing traffic congestion due to unplanned industries in residential zones. Fish, vegetable and raw ingredients processing industries may generate odor and thus pollute the surrounding environment. Another noteworthy pollutant is dust produced from industries causing several health hazards to the people. These issues can be solved if the industries start adopting SDGs goal of sustainability and innovation. In spite of the ongoing efforts of Department of Environment (DOE) in reducing industrial pollution, a number of industries still remain polluters. Because they do not have effluent treatment plants (ETP). Several industries including textile, garments and jute factories have been established without any attention to their environmental consequences. Major polluting sectors also consist of wire and cables, tanneries, brick kilns, cement, pulp and paper, chemical and ship-breaking yards. Although some industries have installed ETP they dump the waste and chemicals on land as solid waste. These ill practices are violation of sustainable development. The 7th FYP plan proposes a new approach to industrial waste management under which community, local institutions, news media and law enforcing agencies and relevant stakeholders will be engaged to mitigate pollution.

Table 4 Disadvantages for Nearby Industry Location

\begin{tabular}{|c|c|}
\hline Types of Disadvantages & Percentage \\
\hline - $\quad$ Noise & $48.6 \%$ \\
\hline - Smoke & $17 \%$ \\
\hline - Odor & $9.3 \%$ \\
\hline - Traffic Congestion & $10.5 \%$ \\
\hline - Dust & $14.6 \%$ \\
\hline
\end{tabular}

Source: Field Survey, 2020

\subsection{Analytic Hierarchy Process (AHP)}

More practicability and utility are crucial for accurate result in applying different scientific methods especially different software in a project. Based on different criteria different methods are developing for example AHP follows (Table 5) mathematical logic. This method adopted geometric weighting to calculate normal weights. Then AHP method was tested in different geo-referenced decision making. Subjective judgment was used to get the criteria weights.

Table 5 AHP Calculation

\begin{tabular}{|c|c|c|c|c|c|c|c|c|}
\hline Criteria & Temperature & $\begin{array}{c}\text { Slop } \\
\text { e }\end{array}$ & $\begin{array}{l}\text { Water } \\
\text { body }\end{array}$ & $\begin{array}{c}\text { Land } \\
\text { Use }\end{array}$ & $\begin{array}{l}\text { City } \\
\text { Center }\end{array}$ & $\begin{array}{l}\text { Rail } \\
\text { way } \\
\text { / Road }\end{array}$ & $\begin{array}{l}\text { Structure/ } \\
\text { Labor Cost }\end{array}$ & $\begin{array}{l}\text { Normal } \\
\text { Weight }\end{array}$ \\
\hline $\begin{array}{ll}\text { - } & \text { Temperatur } \\
\mathrm{e}\end{array}$ & 1 & $1 / 6$ & $1 / 8$ & $1 / 5$ & $1 / 6$ & $1 / 5$ & $1 / 7$ & 0.2812 \\
\hline - Slope & 6 & 1 & 1 & 5 & 7 & 5 & 5 & 2.7015 \\
\hline - Water body & 8 & 1 & 1 & 7 & 7 & 7 & 7 & 3.0988 \\
\hline - $\quad$ Land Use & 5 & $1 / 5$ & $1 / 7$ & 1 & 3 & 1 & 1 & 0.8860 \\
\hline - City Center & 6 & $1 / 7$ & $1 / 7$ & $1 / 3$ & 1 & 3 & 3 & 0.7408 \\
\hline $\begin{array}{l}\text { - Rail way/ } \\
\text { Road }\end{array}$ & 5 & $1 / 5$ & $1 / 7$ & 1 & $1 / 3$ & 1 & 3 & 0.6473 \\
\hline - $\quad$ Structures & 7 & $1 / 5$ & $1 / 7$ & 1 & $1 / 3$ & $1 / 3$ & 1 & $\begin{array}{c}0.5805 \\
\text { Sum: } 8.936 \\
1\end{array}$ \\
\hline
\end{tabular}


This Table 6 is identified as matrix A1. The normal weight of criterion is calculated by adding the scores of a row with power equal to the total number of criterion. A2 matrix is originated from dividing each of the normal weights by the summation of normal weights of matrix A1. Multiplying A1 and A2 matrix generates matrix A3. A4 matrix is the ratio of A3 matrix to A2 matrix.

Table 6 AHP Calculation

\begin{tabular}{c|c|c}
\hline A2 Matrix (Weights) & A3 Matrix & A4 Matrix \\
\hline 0.0315 & 0.1826 & 5.8039 \\
0.3023 & 3.5062 & 11.5980 \\
0.3468 & 3.9181 & 5.9268 \\
0.0991 & 0.5876 & 6.2368 \\
0.0829 & 0.5170 & 5.1794 \\
0.0724 & 0.3752 & 7.0000 \\
0.0650 & 0.4548 & Average: 7.5776 \\
\hline
\end{tabular}

From the table it can observed that the average value of A4 matrix is 7.57. That means the value of $\lambda_{\max }$ is 7.5776 .

$$
\begin{aligned}
C I & =\frac{\lambda \max -n}{n-1} \\
& =7.5776-7 / 7-1 \\
& =0.096
\end{aligned}
$$

The derivation from consistency is provided by consistency index (CI). CI provides the deviation from consistency and then consistency ratio $(\mathrm{CR})$ was calculated.

$\mathrm{CR}=0.096 / 1.35$

$$
=0.0711<0.1
$$

1.35 is the value of random index (RI). It is a randomly generated pair-wise matrix. The final step of AHP is to combine the following equation of suitability index $(\mathrm{S})$

$$
\mathrm{S}_{\mathrm{i}}=\sum \mathrm{w}_{\mathrm{i}} *_{\mathrm{x}_{\mathrm{i}}}
$$

\subsection{Overall Suitability Analysis}

The results shown in Figure 5 (a) was obtained from using predefined GIS tools like polygon to raster, Euclidean distance, reclassify, weighted overlay and raster calculator. According to the results, it was seen that there are a very few suitable lands. Most of the lands are not suitable for building industries. Because Khulna City Corporation area is considered as build up area and there are a very few vacant lands. Individual thematic layers were multiplied by the respective priority vector obtained from the pair wise comparison matrix of Analytical Hierarchy Process. Suitability map of the region were classified from less suitable to most suitable based on the evaluation of the criteria. And also weightages were given to them at criterion level as well as attribute level. According to the analysis it is shown that about $10 \%$ land is most suitable for industrial location, about 7\% land is moderately suitable and $83 \%$ land is not suitable for building new industries.

\subsection{Sensitivity Analysis (Suitable area after $5 \%$ increase in vacant land)}

Sensitivity analysis is usually done to check the uncertainties and variations of the criteria. Naturally uncertainty prevails while dealing with the problems of the real world. To analyze the situation in a better way sensitivity analysis was taken as an option to address the issues. This analysis is usually done because most of the time criterion values are provided by humans and have inherent bias towards some criteria selected in any of the problem considered for MCDM. Small changes were made in the values of priority vector such that the land use and value of the priority vector vacant land rises 5 percent and vector values remaining priority are reduced by 5 percent. According to Figure 5 (b) it was observed that after increasing the priority vector of land use land cover about $5 \%$, the amount of most suitable and moderate suitable land for establishing industries has increased. The amount of most suitable land and moderate suitable land has raised up to $17 \%$ and $12 \%$ where there is a decrease in percentage of less suitable land. 
(a)

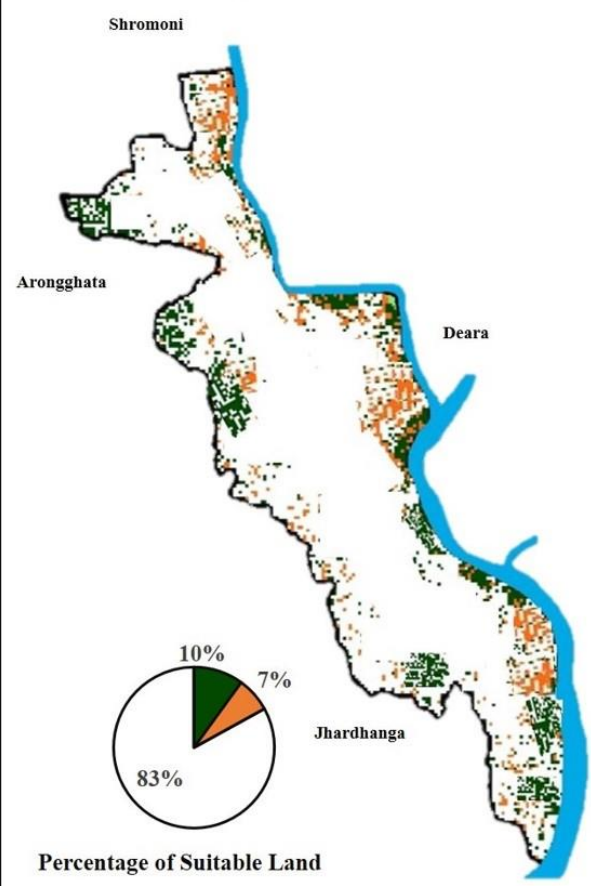

(b)

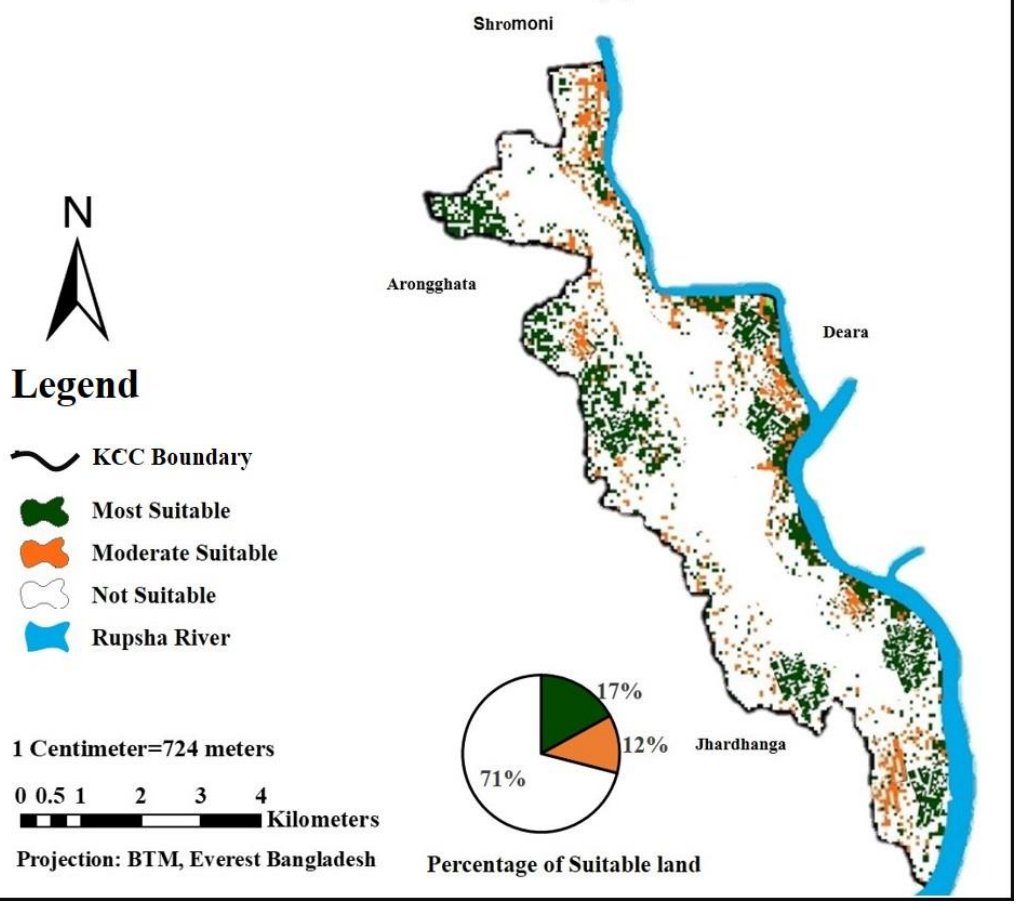

Figure 5 (a) Proposed suitable area inside the KCC (on the basis of existing land use); (b) Proposed suitable area inside the KCC subject to the uncertainty (For 5\% increase in vacant land) (Author, 2020)

\section{Way Forward to SDG's}

The present condition of industrial location in Khulna City Corporation is somehow dissatisfactory in achieving its desired goals. Findings show that relocating industries to a suitable location has long-term advantages. As soon as the construction of Padma Multi-purpose Bridge finishes it will create a huge economic diversity in the southern region. Dhaka will be the mother city and Khulna will be the dormitory city as people will come here for work and leave after work. Thus, transportation of goods and services will be swift and economic condition will flourish. Considering all these if we can achieve new location for industrial setup we will be able to accomplish SDGs goal. The current location of industries are not quite effective for sustainable industrialization.

To modify this the industrial structures should be built considering its surrounding whether it is near residential zone, water bodies or near town periphery. In order to select suitable sites for industrial relocation in Khulna City Corporation, this target can work as a substantial goal. The current location of industries in KCC rarely maintained locational suitability. As a result long term sustainability of industries are not ensured. Thus, selecting suitable locations for industrial zone is vital in accomplishing SDGs $9^{\text {th }}$ goal. $\mathrm{KCC}$ is lagging behind in achieving this goal of sustainable and resilient infrastructural location of industries. The findings show that most suitable area for establishing industrial zone in $\mathrm{KCC}$ is the north-east side of town periphery, the area along Bhoirab River. This will reduce the direct effect of industrial activities on residential areas and protect it from possible hazards. Moreover, selecting such sites will make the city more resilient to any harm emanating from industries such as chemical substances and explosives. These are all related to SDGs goal 9 which work towards building a resilient and inclusive environment for human habitat as well as economic development of the city simultaneously. Again, river side industrial sites have easy and effective transportation medium to distribute products efficiently and increase in input and availability of raw materials.

With climate change impacts the occurrence and degree of natural calamities are expected to increase with greater devastative effects not only on infrastructure but also on lives and livelihoods of people. Bangladesh will need to mainstream the possible impact of these natural blows in building infrastructure. Bangladesh also experiences damage caused by manmade disasters such as structure collapse and fire. In this regard, the mainstream has to be planned methodically based on scientific assessment of the impacts of climate change. Bangladesh has already begun to implement such projects. The implementation of such projects should be expanded and integrated under the Delta Plan 2100. The synopsis of achieving sustainable industrialization is as follows in Figure 6- 


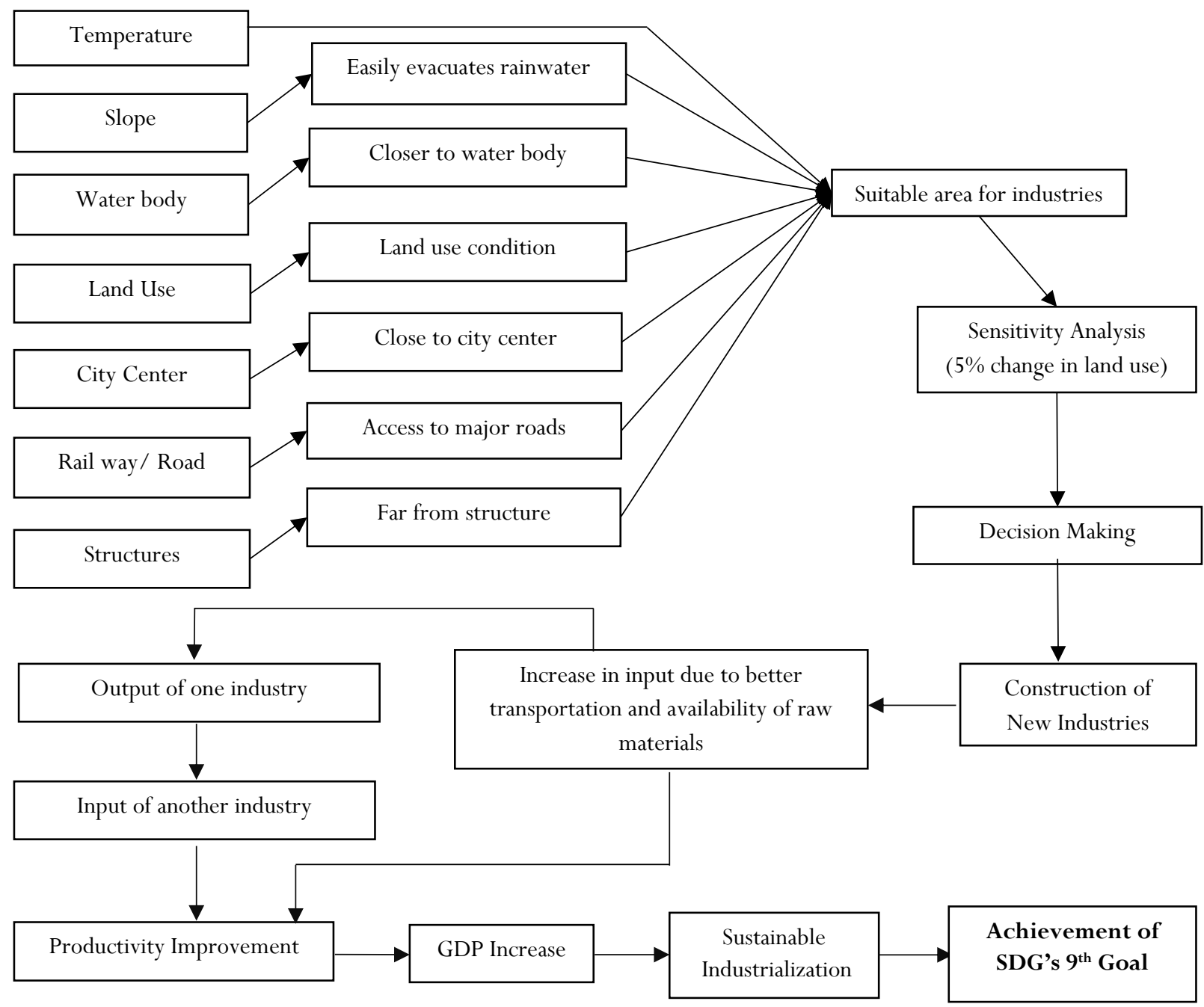

Figure 6 Conceptual framework for achieving SDG (Goal -9) (Author, 2020)

\section{Discussion \& Conclusion}

With the development of Khulna city, it is becoming a hub of industries and after the construction of Padma bridge a connection will establish with Dhaka and other major cities. Also, for achieving inclusive and sustainable industrialization (UN's $9^{\text {th }}$ goal), proper site selection is one of the major priorities. The spatial form of identification of potential industrial sites and the need to include the preferences of the decision maker in the analysis requires a combination of GIS and MCDA methods. Main factors being land use and land cover, distance from structures, city center, distance from water body, slope, viable road network to make the work easier at least in the initial stages. Existing location of industries was identified and according to the analysis results it was found that some of the industries are situated in suitable location and some of the industries are in unsuitable location. Evaluation process was conducted with the help of some expert opinions and personal perspective that provided the necessary judgment to fill the comparison matrix. Suitability maps were generated by using AHP. The search for potential industrial sites using different techniques gives us a better picture to assess the problems associated with it. Uncertainty is an inherited characteristic, while dealing with the problems of the real world. Therefore, a sensitivity analysis by modifying the weights of criteria to a certain percentage to estimate changes in the area within classes of convenience and to decide the right place was performed. After performing sensitivity analysis the amount of suitable and moderately suitable areas increases where the amount of less suitable land decreases. An analysis of land suitability based on GIS extends the use of operators overlap with the preferences of the decision maker. Some of the multi criteria methods have to be investigated later to get better results. Development of new computational methods in GIS environment makes it interesting to improve efficiency in the evaluation of the process of industrial establishment. However, selection of suitable industrial site will not only help to promote inclusive and sustainable industrialization and by 2030 but also it will help to raise industry's share of employment and gross domestic product. 


\section{References}

Ahmmed, M. U., Ahmed, M. U., Howlader, M. R., Prodhan, E. H., Miah, M., \& Abdullah, M. (2013). District statistics 2011 Khulna. Dhaka: Bangladesh Bureau of Statistics (BBS).

Bangladesh Planning Commission, M. o. (2018). Sustainable Development Goals: Bangladesh Progress Report 2018. Dhaka: General Economics Division (GED).

Bangladesh Statistics . (2018). Dhaka: Bangladesh Bureau of Statistics (BBS) Statistics and Informatics Division(SID) Ministry of Planning.

Boutkhoum, O., Hanine, M., Agouti, T., \& Tikniouine, A. (2014). An Improved Hybrid Multi-Criteria/ Multidimensional Model For Strategic Industrial Location Selection: Casablanca Industrial Zones As A Case Study. Springerplus, 628: 1-23 DOI 10.1186/s40064-015-1404- $\mathrm{x}$

Economic Census 2013 District Report: Khulna. (2016). Dhaka: Reproduction, Documentation \& Publication (RDP) Section Bangladesh Bureau of Statistic.

Fataei, E., erdi , M. A., Farhadi, H., \& Mohammadian, A. (2015). Industrial State Site Selection Using MCDM. Journal of Industrial and Intelligent Information, 8: 324-329. doi: 10.12720/jiii.3.4.324-329

Fernando, G., Pinnawala, V. P., \& Edussuriya, C. (November-2015). A GIS Model For Site Selection of Industrial Zones In Sri Lanka (A case study of Kesbewa divisional secretariat division in Colombo district) . International Journal of Scientific \& Engineering Research. 6(11):171-175.

Goodwin, K. (2018, February 21). Property Matrics. Retrieved July 10, 2020, from https:// propertymetrics.com/blog/location-quotient/

Gupta , S. K., \& Racherla, U. S. (2016). Effect of ISO 14000 sertification on sustainability:. The Journal of social, political, and economic studies, 41(1): $34-50$.

Hadipour, M., \& Kishani, M. (2014). Environmental Location Planning of Industrial Zones Using AHP and GIS In Arak City, Iran. Globalllluminators, 1: 109-114.

Haque, M. N., Mamun, M. A., Saroar , M. M., \& Roy, T. K. (2019). Application of "DPSIR" Framework To Assess The Status And Role of Blue Ecosystem Services (BES) in Khulna City. Journal of Engineering Science 10(2): 49-60.

Islam, M. K., Banik, S. C., Sakib, N., \& Begum, N. N. (2018). MultiCriteria Decision-Making Tool for the Safety of Bangladeshi Industries Using Fuzzy Logic. International Journal of Production Engineering, 4(1): 29 38.

Islam, M. M., Hossain, A. F., Abbas, S., Silvy, S., \& Hasan, M. S. (2020). A Study on Impacts, Construction Challenges And Overcomes of Padma Multipurpose Bridge, Bangladesh. 5th International Conference on Civil Engineering for Sustainable Development. Khulna: (ICCESD 2020), 7 9 February 2020, KUET, Khulna, Bangladesh.
Islam, M. S., Bhattacherjaa, P., \& Fatema, J. T. (2019). Green Industry Development In Bangladesh. TECH MONITOR, 20-24.

Johar, A., Jain , S., \& Garg , P. (2013). Land Suitability Analysis For Industrial Development Using GIS. Journal of Geomatics, 7(2): 101-106.

Khulna newsprint mills (KNM). (2008, May 13). Retrieved July 11, 2020, from Priobangla: http://priobangla.net/bangladesh-touristspots/details/khulna-newsprint-mills-knm-undefined-khulna-548/

M, S., Saran, S., \& Ramana, K. V. (2018). Site Suitability Analysis For Industries Using GIS And Multi Criteria Decision Making . ISPRS Annals of the Photogrammetry, Remote Sensing and Spatial Information Science, IV(5), 447-454. https://doi.org/10.5194/isprs-annals-IV-5-447-2018

Moses, A., Iwara, E., Gbadebo, N. C., Olubukola, O. O., \& Omin, I. P.-C. (2018). Geographic Foci of Industries: A Suitability Analysis. Journal of Geography, Environment and Earth Science, 14(1): 1-14.

Nations, U. (2015). Industry and Infrastructure. Retrieved 7 19, 2020 , from https://www.sightsavers.org/policy-andadvocacy $/$ globalgoals $/$ ?gclid=CjOKCQjw3s_4BRDPARIsAJsyoLOAdt Y1zoTR1W3-qCwaaWXiZZf59r ZfJO6740fjGh8zB7LiCTNVlsaArsuEALw_wcB

NATIONS, U. (2018). Transforming Our World: The 2030 Agenda For Sustainable Development.

Partha, D. B., Mohaimin, M. H., \& Islam, M. S. (2018). Assessment of Noise Level And Its Impacts on Health In Different Industries Located In Khulna City. 4th International Conference on Advances in Civil Engineering 2018 (ICACE 2018) 19 -21. Chittagong.

Paul, T. C. (2019, May 21). The Financial Express. Retrieved July 20, 2020, from Bangladesh: Journey Towards Achieving Sustainable Development Goals (SDGs) https: / / thefinancialexpress.com.bd/views/bangladesh-journeytowards-achieving-sustainable-development-goals-sdgs-1558451988

Rahman, S. T., \& Kabir, A. (2019). Factors Influencing Location Choice And Cluster Pattern of Manufacturing Small And Medium Enterprises In Cities: Evidence From Khulna City of Bangladesh. Journal of Global Entrepreneurship Research. 9(61): 1-26. https://doi.org/10.1186/s40497-019-0187-x

Rikalovic, A., Cosic, I., \& Lazarevic, D. (2014). GIS Based MultiCriteria Analysis for Industrial Site Selection . ELSEVIER, 69: 1054-1063. DOI: $10.1016 /$ j.proeng.2014.03.090

Rikalovic, A., Cosic, I., Labati, R. D., \& Piuri, V. (2017). A Comprehensive Method for Industrial Site Selection: The MacroLocation Analysis. IEEE Systems Journal, 69: 12. DOI: 10.1109/JSYST.2015.2444471

S., F. P. (1937). Economic Research And Industrial Policy. The Economic Journal, 5(2): 621-641.

Salam, S. (2016). Structure And Future Development of The Service Sector In Bangladesh. European Journal of Service Management 20: 49-55. 
Statisics and Information Division, M. o. (2013). District statistics 2011 khulna. Dhaka: Bangladesh Bureau of Statistics (BBS).

Statistics and Informatics Division (SID), B. B. (2013). Survey of Manufacturing Industries 2012 (SMI 2012). Dhaka: Bangladesh Bureau of Statistics.
Statistics And Informatics Division, M. O. (2013). District Statistics 2011 Khulna. Dhaka: Bangladesh Bureau of Statistics (BBS) .

Wang, D., \& Hofe, D. v. (2007). Research Methods In Urban And Regional Planning. New York: Springer Berlin Heidelberg.

Zahedi, F. (1986). The Analytic Hierarchy Process-A Survey Of The Method And Its Applications. Institute for Operations Research and the Management Sciences (INFORMS, IV(16), 96-108 